\title{
Stratigraphy and Depositional Model of Palaeogene Dongying Braided-River Delta Sandstones, L Field, Bohai Bay Basin, Offshore Eastern China
}

\author{
Qianping Zhang ${ }^{1}$, Zongbin Liu ${ }^{1}$, Xinwu Liao ${ }^{1}$, Hongying $\mathrm{Li}^{1}$, Yujuan $\mathrm{Liu}^{1} \&$ Bin Zheng ${ }^{1}$ \\ ${ }^{1}$ Bohai Oil Field Research Institute, Tianjin Branch of CNOOC Ltd., Tianjin 300459, China \\ Correspondence: Qianping Zhang, Bohai Oil Field Research Institute, Tianjin Branch of CNOOC Ltd., Tianjin, \\ 300459, China. Tel: 86-020-66500898. E-mail: zhangqp4@cnooc.com.cn
}

Received: March 13, 2019

Accepted: May 9, 2019

Online Published: August 7, 2019

doi:10.5539/esr.v9n1p1

URL: https://doi.org/10.5539/esr.v9n1p1

\begin{abstract}
Fluid production of L field, Bohai Bay Basin, offshore eastern China is mainly from the Palaeogene Dongying D interval. The stratigraphy framework and depositional model of the braided-river delta system within the D interval are investigated using seismic, well log, core data and production response. The $\mathrm{D}$ interval is interpreted as having been deposited in a lowstand system tract. And two progradational successions are recognized, including in ascending order the D2 and D1. The younger sandstone in the D1 interval is of greater thickness and larger distribution area than the elder sandstone in the D2 interval. Six core facies and five log patterns are recognized and interpreted to be underwater distributary channels, levees, overbank splays, mouth bars, sheet sand and shalier interchannel deposits. Channel deposits occur along the trend of thickest D2 and D1 sandstones. The sandstones that flank each side of the channel deposits are interpreted to be levee and overbank splay deposits. The sandstones that develop at terminal distributary channel mouth are interpreted to be mouth bar and sheet sand deposits. Channel-flank deposits can form good-quality reservoir sandstones, but they contain interbedded siltstones and thus have lower porosity and permeability than do channel deposits. The facies distributions predicted for the $\mathrm{D}$ interval match trends of the daily total fluid production. Knowledge gained from study of the L field has application to the development of other fields with similar depositional and diagenetic histories.
\end{abstract}

Keywords: Bohai Bay Basin, stratigraphy, depositional model, reservoir performance, braided-river delta

\section{Introduction}

Braided-river delta is one of the common sedimentary types in terrestrial basins. It can be discovered in Ordos Basin, Tarim Basin, Bohai Bay Basin, etc. in China (Zhu et al., 2013; Zhu et al., 2013; Dong, Yang, Chen, Wang, \& Cao, 2014; Zhu et al., 2016). Since 1990s, braided-river delta has become a hotspot for oil and gas exploration and development (Yu, Wang, \& Sun, 1995; Li, Lin, Yuan, \& Wang, 1996).

Some important studies of braided-river delta in China have been described. Wang, Yang, Bian, Luo and Wen (2012) obtained the contrast modes and laws for the subdivision of braided-river delta front sand bodies. Yin, Yu and $\mathrm{Lu}$ (2006), Tian et al. (2011) and Zhu et al. (2016) studied the lithology, texture and sedimentary structure of braided-river deltas. Zhang et al. (2013) and Lan et al. (2014) described the controlling factors of braided-river delta reservoir quality. Wen et al. (2012) conducted a sedimentation simulation experiment. Wang, Sun, Zhang and Ma (2008), Wang (2010) and Liang et al. (2011) reported that together with specific structural settings, braided-river deltas can form many types of favorable petroleum accumulation zones. Compared with these studies, we discussed the stratigraphic framework and depositional model of the braided-river delta sandstones within the second member of Palaeogene Dongying Formation, L field, Bohai sea, eastern China.

In Bohai Sea, the Paleogene sand-rich sedimentary systems are dominated by various deltas. The structure activity is mainly overall subsidence during the deposition of the second member of Dongying Formation, resulting in the predominance of braided-river deltas, with a total area of $13600 \mathrm{~km}^{2}(\mathrm{Li}, \mathrm{Zhou}, \& \mathrm{Lv}, 2011)$.

In-place oil resources within the Liaodong Bay are estimated to total 1.3 billion ton and the proved reserves are primarily contained within reservoirs of the lower part of the second member of Dongying Formation, accounting for nearly 75\% (Wang, Wang, Lv, \& Fan, 2011; Li, Dai, \& Yu, 2006). One such reservoir is the 
second member of Dongying Formation at L field (Figure 1). Estimate of proved oil reserves is nearly 314 million bbl (50 million $\left.\mathrm{m}^{3}\right)$ at $\mathrm{L}$ field.

The efficacy of production schemes is dependent on the accurate depiction of preferred reservoir intervals (Zhu, 2008). This study predicts occurrence of depositional facies in wells that lack core control and the spatial distribution of depositional facies within a time stratigraphic framework, in which this distribution corresponds to historic trends of fluid production.

14 large oil fields and 25 hydrocarbon-bearing structures have been discovered in the Liaodong Bay till 2011(Wang et al., 2011). Knowledge gained from study of the L field has application to the development of other fields with similar depositional and diagenetic histories.

\section{Geological Setting}

The $\mathrm{L}$ field is located offshore along the middle Liaoxi low uplift, Liaodong Bay depression within the Bohai sea of eastern China (Figure 1). The field is bounded by faults to the NW and extends into depression to the SW.

The NE-SW trending Liaodong Bay depression was uplifted during the late Mesozoic. And the Cenozoic evolution was divided into two stages: rifting during the Paleogene and post-rifting from the Neogene to Quaternary (Wang et al., 2011). Three large fault systems: the linked Liaoxi extensional fault system, the Liaodong extensional fault system and the Tan-Lu strike-slip fault system dominate the structure. The fault systems mostly elongates to the NE-SW direction. The depression consists of three major sags (Liaoxi, Liaozhong and Liaodong) and two low uplifts (Liaoxi and Liaodong) (Xu et al., 2011; Ji, 2008; Zhu et al., 2008). Most sags in the depression are characterized by inclined basement surfaces overlain by Cenozoic strata. The basement rocks include Mesozoic volcanic rocks, Paleozoic carbonate rocks and Archean metamorphic rocks (Wang et al., 2011; Lv et al., 2009). The syn-rift strata comprise the Shahejie and Dongying formations that are widely distributed in the area (Yang et al., 2008).

The lithostratigraphy in the L field area is made up of Paleozoic carbonate basement unconformably covered with Cenozoic clastic and carbonate sediments. At L field, oil is produced from the second member of the Paleogene Dongying Formation (Wang et al, 2013). It consists of braided-river delta sediments. Five oil layers are correlated across L field, and their stratigraphic designations are referenced sequentially relative to their position (from top to bottom are 0 , I, II, III, and IV). The II oil layer is the thickest and most widespread reservoir, overlain by a large set of mudstones and siltstones below the I oil layer (M1+M2). The D interval at the top of the II oil layer is the primary production layer. Cores are available within the D interval, and therefore, this work is focused on this interval. 

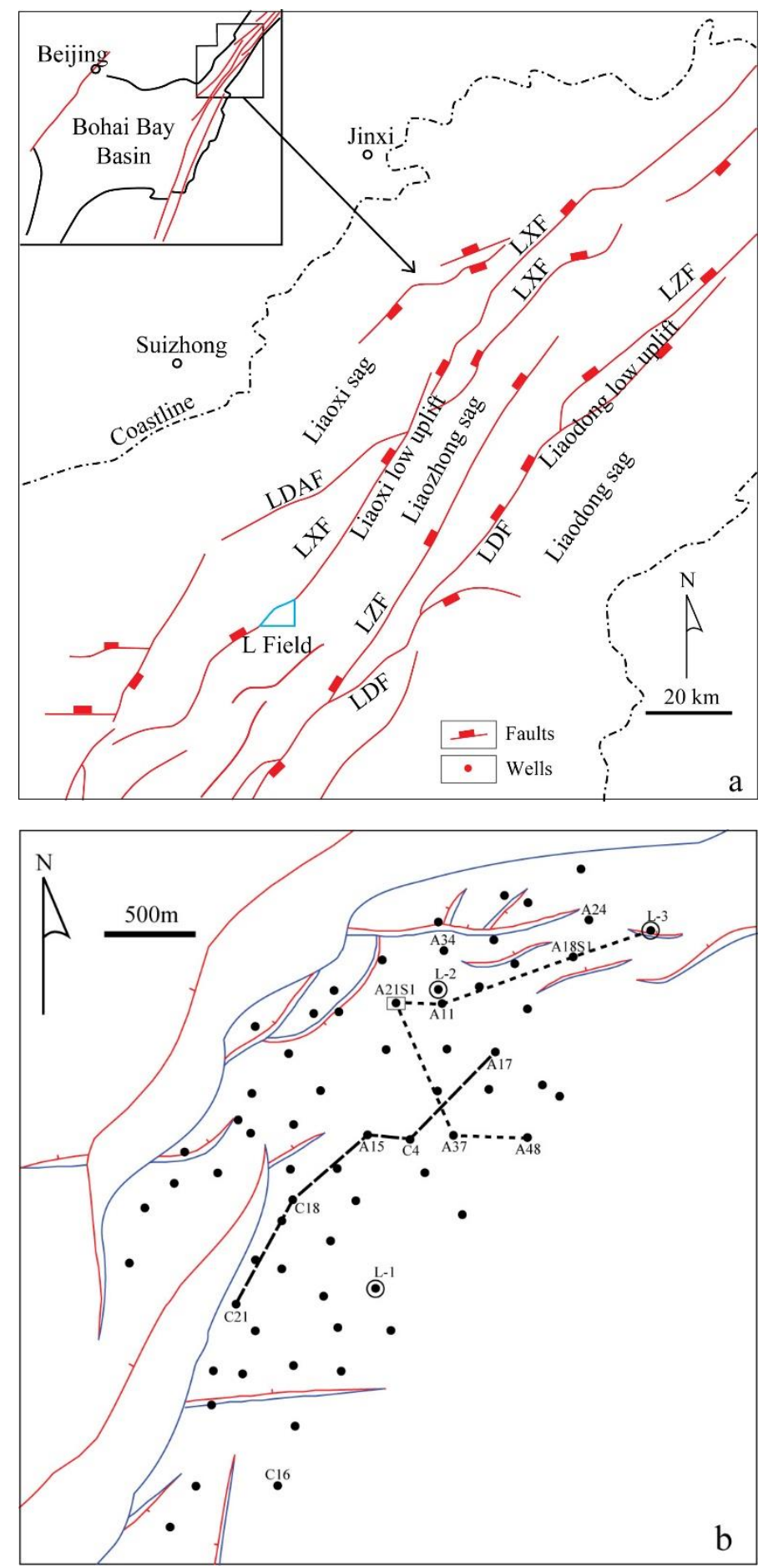

Figure 1. (a) Simplified structural map of Liaodong Bay depression and L field. The filed is marked with a blue frame. LXF, LZF, LDF, and LDAF indicate Liaoxi fault, Liaozhong fault, Liaodong Fault, and Luda fault, respectively. (b) Location of wells included in this study. Abandoned wells are not shown. Certain well numbers are shown. The location of cored well A21S1 is shown with a box. The location of exploratory wells are shown encircled

\section{Stratigraphic Framework}

\subsection{Regional Overview}

The Cenozoic evolution of Liaodong Bay depression includes rifting during the Paleogene and post-rifting 
during the Neogene, which divides the Paleogene and the Neogene into two first-order sequences (Zhu et al, 2008; Wang et al., 2011). Based on the type and distribution of regional unconformities, the Paleogene is divided into four second-order sequences (Zhu et al, 2008; Zhu et al, 2011). Third-order sequence boundaries can be identified through (1) palaeontology grouping changes; (2) obvious rock electrical property changes; and (3) apparent seismic reflection terminations (Zhu et al, 2008; Ji, 2005; Guo, Zhou, Lai, Li, \& Shi, 2011; Guo et al, 2012). Six third-order sequence boundaries are identified within the Paleogene of Liaodong Bay depression, and the Dongying Formation at Liaoxi low uplift consists of three third-order sequences: SQd3, SQd2 and SQd1 (Zhu et al, 2008; Zhu et al, 2011).

\subsection{Seismic Reflection}

The hydrocarbon-bearing zones of L field mainly locate at SQd2. SQd2 is interpreted as a third-order sequence, including a lowstand systems tract (LST), a transgressive systems tract (TST), and a highstand systems tract (HST). In the seismic sections, the top sequence boundary, corresponding to the bottom surface of the first member of Dongying Formation, is marked by seismic toplaps. The bottom sequence boundary is delineated by the reflection interface that separates the second and the third member of Donying Formation. Onlaps are commonly observed but truncations occur at some uplift areas as well. The first flooding surface (FFS) is the internal boundary between LST and TST. The FFS can be readily identified on well log patterns. The boundary between TST and HST is the maximum flooding surface (MFS). It shows continuous reflectors with strong phase (Figure 2).

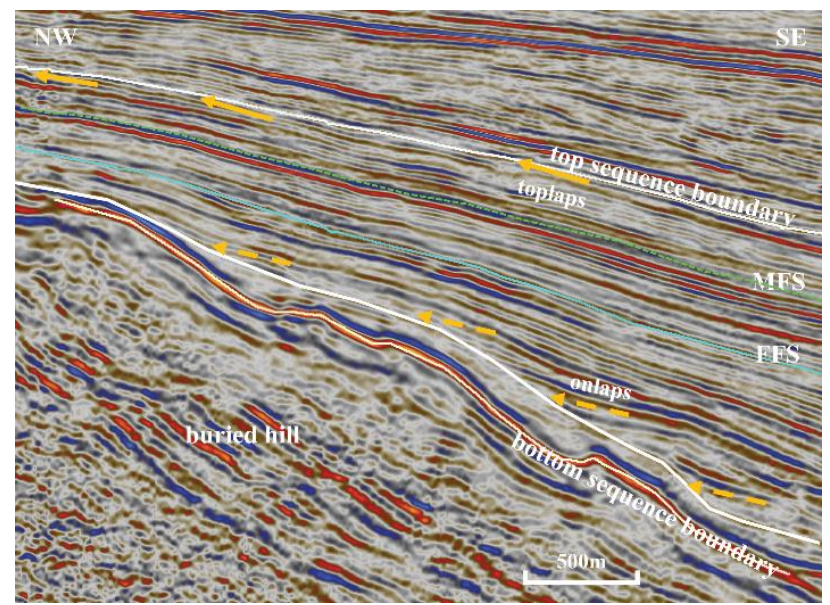

Figure 2. Seismic section (northwest to southeast) across the L field showing sequence interpretation. MFS=maximum flooding surface, $\mathrm{FFS}=$ first flooding surface

\subsection{Vertical Profile}

The second member of the Paleogene Dongying Formation consists of interbedded siltstones, fine-grained sandstones and mudstones at the top $(0, \mathrm{I})$, large sets of mudstones and siltstones in the middle (designated $\mathrm{M} 1+\mathrm{M} 2$ in this paper) and interbedded coarse to fine-grained sandstones, siltstones and mudstones on the bottom (II, III, IV). The D interval is at the most top of theIIoil layer.

The gamma-ray log (Figure 3) through theI, M, and D intervals in Well A21S1 indicates the D interval as coarsening upward, the M1 interval as fining upward and the M2+Iinterval as coarsening upward. The coarsening-upward and fining-upward trends are punctuated by finer materials, interpreted as siltstones and mudstones deposited on flooding surfaces. The coarsening-upward followed by fining-upward feature of the D/M1 suggests progradation followed by retrogradation. And the fining-upward followed by coarsening-upward character of M1/M2+Isuggests retrogradation followed by progradation.

The D/M1 intervals are a progradational parasequence set capped by a retrogradational parasequence set. And the $\mathrm{M} 1 / \mathrm{M} 2+$ Iintervals are a retrogradational parasequence set capped by a progradational parasequence set.

The maximum flooding surface (MFS) typically occurs at the transition from retrogradational to progradational parasequence sets $(\mathrm{Ji}, 2005)$. And MFS typically locates within widely and stably distributed mudstones, which 
appears on the gamma-ray log as the local maximum (Guo et al, 2012). Based on this observation, a maximum flooding surface is inferred at the top of the M1 retrogradational parasequence set.

The first flooding surface (FFS) in L oilfield is like a division surface above which is lacustrine mudstones and below which is thick-bedded delta sandstones (Guo et al, 2012). The FFS is inferred at the top of the D progradational parasequence set.

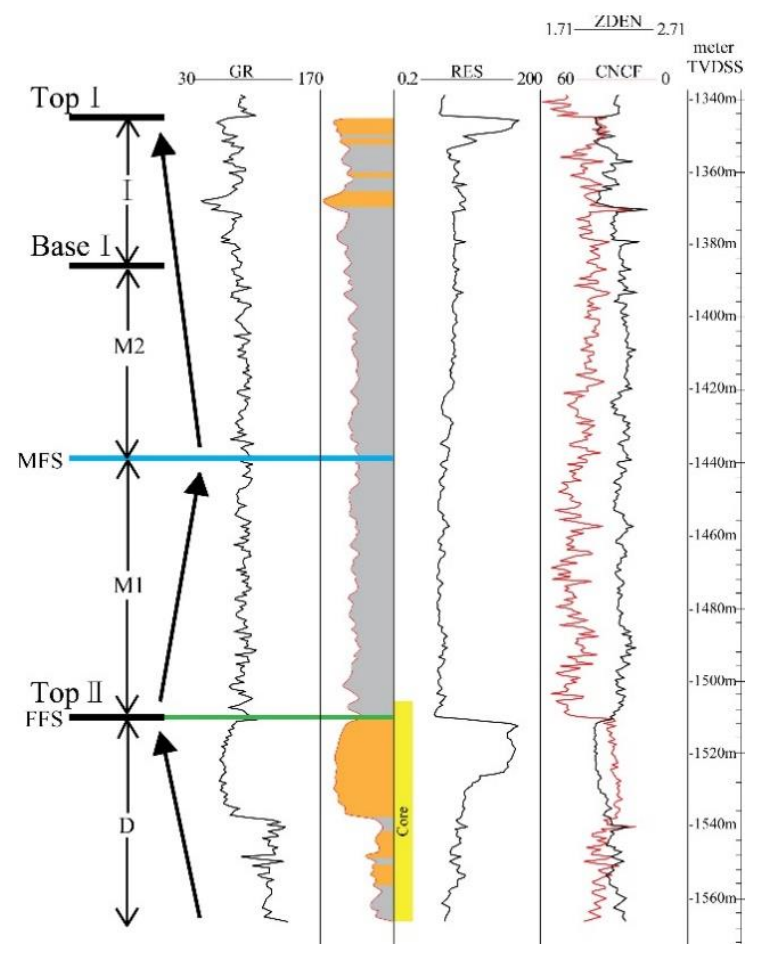

Figure 3. A21S1 well log character of the I, M and D intervals. The M interval, the large set of mudstones and siltstones between the I and II oil layers, is subdivided into M1 and M2 by the maximum flooding surface. Gamma-ray, resistivity and neutron-density logs are shown. Core intervals shown in Figure 4 are indicated.

Lithology interpretations are based on well logs corrected with cores. Arrows show general coarsening upward in the D reservoir interval, followed by fining upward in the M1 interval and then by coarsening upward in the $\mathrm{M} 2+\mathrm{I}$. Blue line indicates the maximum flooding surface. Green line indicates the first flooding surface. The depth is in SSTVD. The location of Well A21S1 is shown in Figure 2b

\subsection{Core Description}

Cores are available through the D interval for Well A21S1 (Figure 4), showing the D progradational parasequence set. Two progradational successions are recognized, including in ascending order the D2 and D1. The following attribute mapping is limited to these two intervals. In core, individual parasequence comprises braided- river delta deposits. The D1 mainly includes medium to coarse grained distributary channel sandstones. Scour surfaces and pebble lags are commonly found at the bottom of channels. The D2 is finer grained, mainly including siltstones and fine sandstones. 


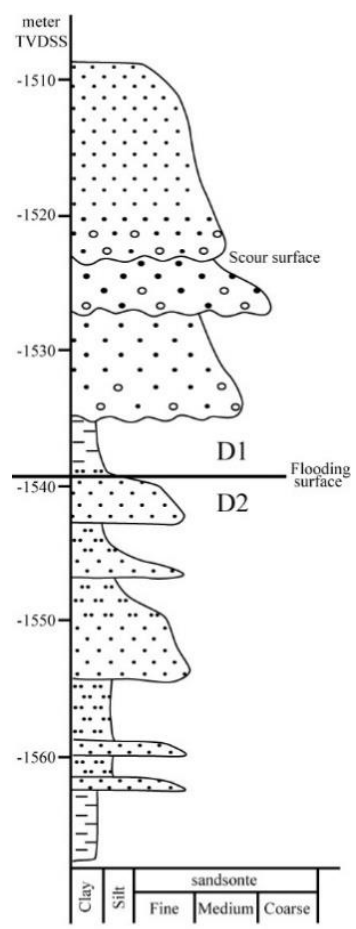

Figure 4. A21S1 core description of the D interval, showing grain size and key sedimentary structures observed in core. The D interval is subdivided into two progradational successions (D2 and D1). The location of the core is shown in Figure 3. The depth is in SSTVD

\section{Reservoir Characterization and Classification}

\subsection{Sandstone Distribution}

The provenance of the second member of Dongying Formation of L field transitions from the northwest (Wang et al, 2013). The lateral variation of both rock compositions in Figure 5a and mean grain size in Figure 5b also indicate a northwest source.
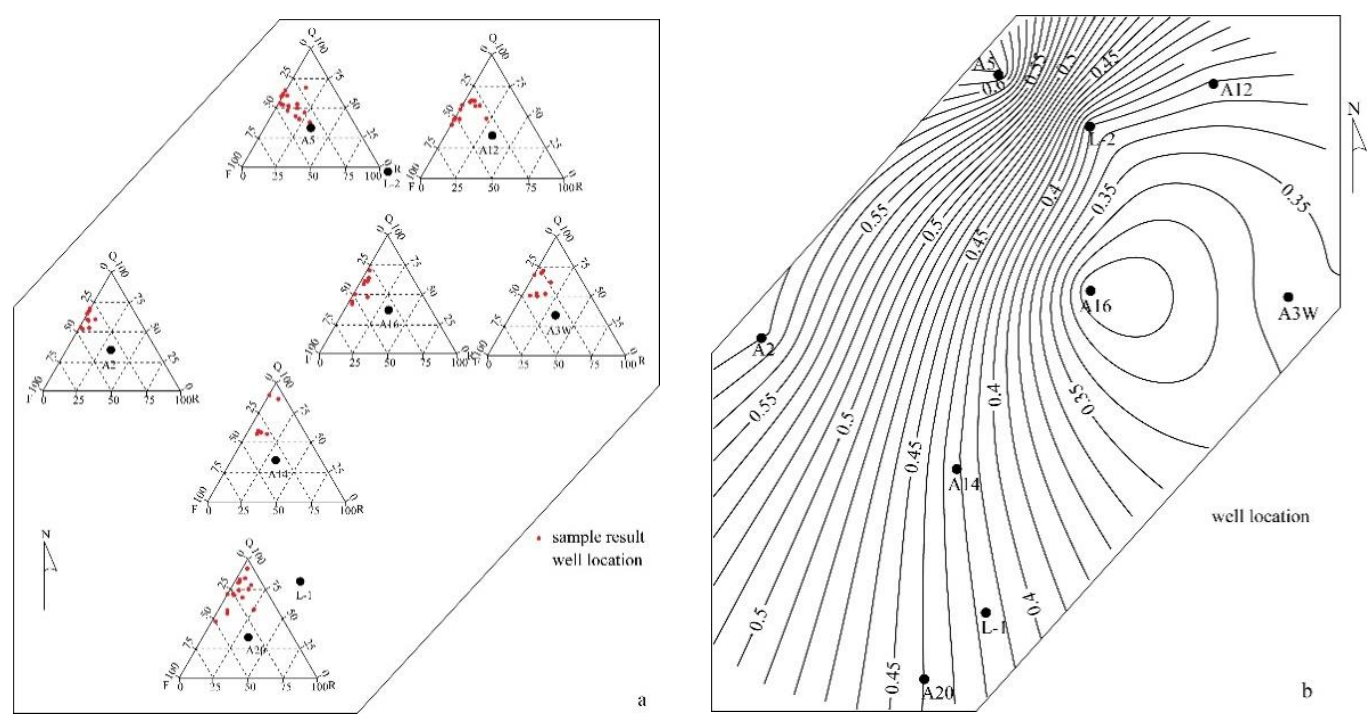

Figure 5. (a) The lateral variation of rock compositions in the second member of Dongying Formation of L field. Samples from wells at the southeast of the field contain higher percentage of quartz, the stable component of sandstones, than those at the northwest. (b) The lateral variation of mean grain size in the second member of

Dongying Formation of L field. The mean grain size decreases from the northwest to the southeast 
The younger sandstone in the D interval, the D1 (Figure 6a), is oriented NNW-SSE. It mainly ranges from 12 to $28 \mathrm{~m}$ in thickness and has a maximum thickness of $34 \mathrm{~m}$. The D1 sandstone widens but pinches out towards the southeastern part of the field. Reservoir sandstones in the D2 interval range from 8 to $24 \mathrm{~m}$ in thickness. And as the D2 sandstone deposited, the Paleozoic carbonate basement of L field, or the buried hill, was locally exposed, separating the D2 sandstone into two parts orienting NW-SE and NNW-SSE, respectively (Figure 6b).

The southwestern boundary is defined by both well data and seismic data. The thickness along the southeastern margin is defined based on the overall sandstone distribution because few wells were drilled where the sandstone is assumed to be charged with water instead of oil.
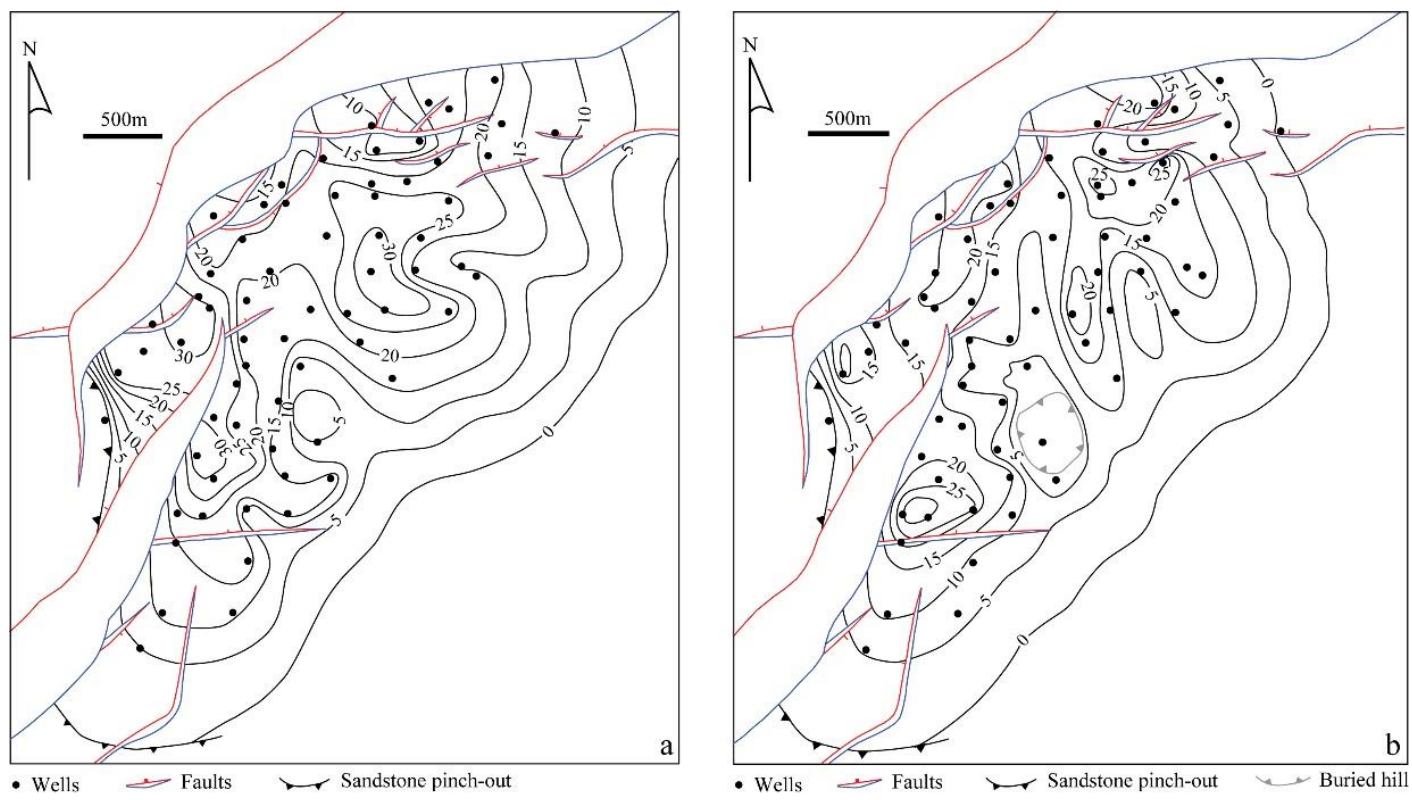

Figure 6. (a) Isopach map of the D1 sandstone. (b) Isopach map of the D2 sandstone

\subsection{Reservoir Facies Prediction}

The $\mathrm{D}$ interval has been studied and interpreted as a braided-river delta complex that has been deposited in a lake basin (Wang et al, 2011). Distinguished on the basis of color, grain size, sedimentary structures and algal fossils, six core facies are recognized and interpreted to accumulate within braided-river delta environments (Figure 7).

Underwater distributary channels are commonly observed within the study area. Coarser grained sandstones were deposited in distributary channels (Figure 7d,e,f) whereas finer grained sandstones were deposited in channel-flank environments (Figure 7b,c). Erosion surfaces overlain by pebble lags occur along the base of distributary channels (Figure 7f). Cores have been water-flooded and are poorly cemented, so that sedimentary structures such as trough cross-bedding are rarely observed. 


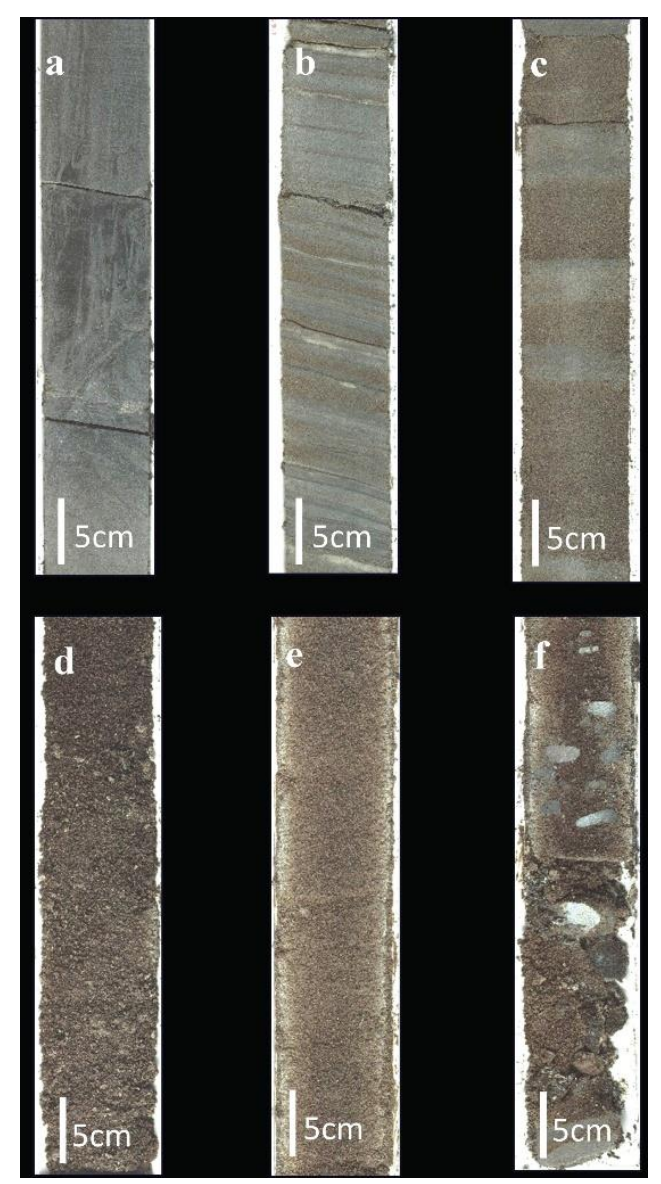

Figure 7. Core photos representative of facies observed within the D interval of Well A21S1 at L field. (a) Facies a. massive and laminated mudrock at $1508.8 \mathrm{~m}$. (b) Facies b. lenticular to wave bedded silt at $1545.4 \mathrm{~m}$. (c) Facies c. flaser bedded fine-grained sandstone at $1550.2 \mathrm{~m}$. (d) Facies d. massive coarse-grained sandstone at $1525.5 \mathrm{~m}$. (e) Facies e. massive medium-grained sandstone at $1534.2 \mathrm{~m}$. (f) Facies f. pebbly medium-grained sandstone at $1535.8 \mathrm{~m}$. Pebble lags are observed. Note the scour surface at the bottom. In braided-river delta front successions, scour surfaces are commonly found at the bottom of distributary channels. Photo brightness has been increased

by $40 \%$ compared to the original in order to highlight core features. Scale bar $=5 \mathrm{~cm}$. The depth is in SSTVD

In the subsurface, continuous cores are needed to record fully the details of deposits. However, only limited cores are available in the $\mathrm{L}$ field, thus well logs must be used to delineate reservoir facies. Well logs have been proved valuable in identifying various deposits by their vertical profile (Du et al., 2013; Li and Huang, 2017; Qi et al., 2018). Examples are shown in Figure 8. 

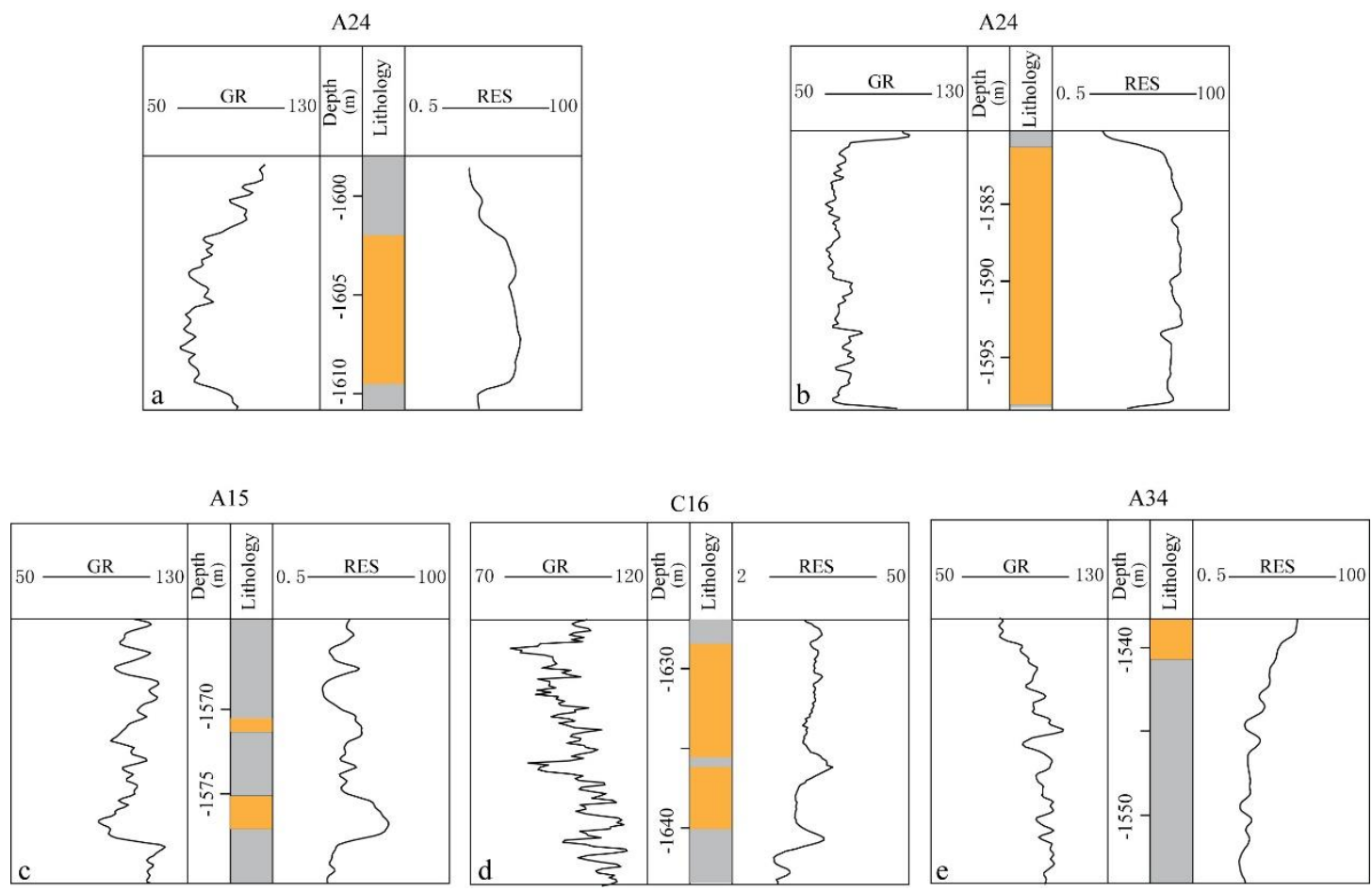

Figure 8. Diagram showing well log representation of braided-river delta sediments. Bell (a) and box (b) shaped well $\log$ responses to distributary channels. (c) Bell shaped well log responses to levees flanking distributary channels. The thickness gets smaller and interbedded mudstones and siltstones are more developed. (d) Funnel shaped well log responses to splays and mouth bars. (e) Well log responses to the shalier deposits of interchannel environments. The depth is in SSTVD. Gamma-ray and resistivity are shown. Lithology is interpreted and classified into mud and sand based on well logs corrected with cores

\subsection{Reservoir Properties}

Core samples were collected from the second member of Dongying Formation with the depth ranging from $1647.5 \mathrm{~m}$ to $1758.6 \mathrm{~m}$ of Well A21S1 and $1556.7 \mathrm{~m}$ to $1585.7 \mathrm{~m}$ of Well L-2. Sixty nine sidewall cores were collected from Well L-1 and Well L-2. Over one thousand times of analysis including conventional core analysis, thin section analysis, scanning electron microscope analysis, etc. were conducted. Well logs are corrected with core samples for porosity and permeability interpretation.

The D sandstone is medium-sorted, medium-rounded and fine to coarse grained arkoses. Porosity ranges from $25 \%$ to $31 \%$ and permeability ranges from 400 to $2500 \mathrm{mD}$.

Underwater distributary channel sandstones have higher porosity and permeability, with porosity ranging from $29 \%$ to $35 \%$ and permeability from 1000 to $5500 \mathrm{mD}$. Porosity in mouth bar deposits ranges from $25 \%$ to $31 \%$; permeability ranges from 300 to $2200 \mathrm{mD}$. Channel-flank deposits have lower qualities, with porosity from $23 \%$ to $28 \%$ and permeability from 350 to $2000 \mathrm{mD}$.

\section{Depositional Model}

The D interval in L field are interpreted to have been deposited in a braided-river delta system with underwater distributary channels, levees, overbank splays, mouth bars, sheet sand and shalier interchannel deposits (Figure 9, 10). The interpretation is made on the basis of core observations, log patterns, sandstone thickness and trends, and production response. The D interval is divided into D1 and D2. Mudstones deposited above flooding surfaces between D1 and D2 can be mapped throughout the reservoir, with the thickness mainly ranging from 1 to $4 \mathrm{~m}$. However, they may be poorly developed where sand-rich facies overlie other sand-rich facies.

In core, at least three channels are seen to be nested in the D1 interval (Figure 4). Similar nesting of multiple channels may occur in L field, but the well control is not sufficiently close to distinguish separate channels. So that the channels in the D1 and D2 intervals are vertically single channels are assumed.

Channel deposits are interpreted to occur along the trend of thickest D1 and D2 sandstones. They stretch out 
from the northwestern towards the southeastern part of the field. Sandstones that flank each side of channels are interpreted to be levees and overbank splay deposits and are inferred to be continuous with channel sandstones. Channel-flank deposits can form good-quality reservoir sandstones, but they contain interbedded siltstones and thus have lower porosity and permeability than do channel deposits. The sandstones that develop at terminal distributary channel mouth are interpreted to be mouth bar and sheet sand deposits (Figure 9, 10).

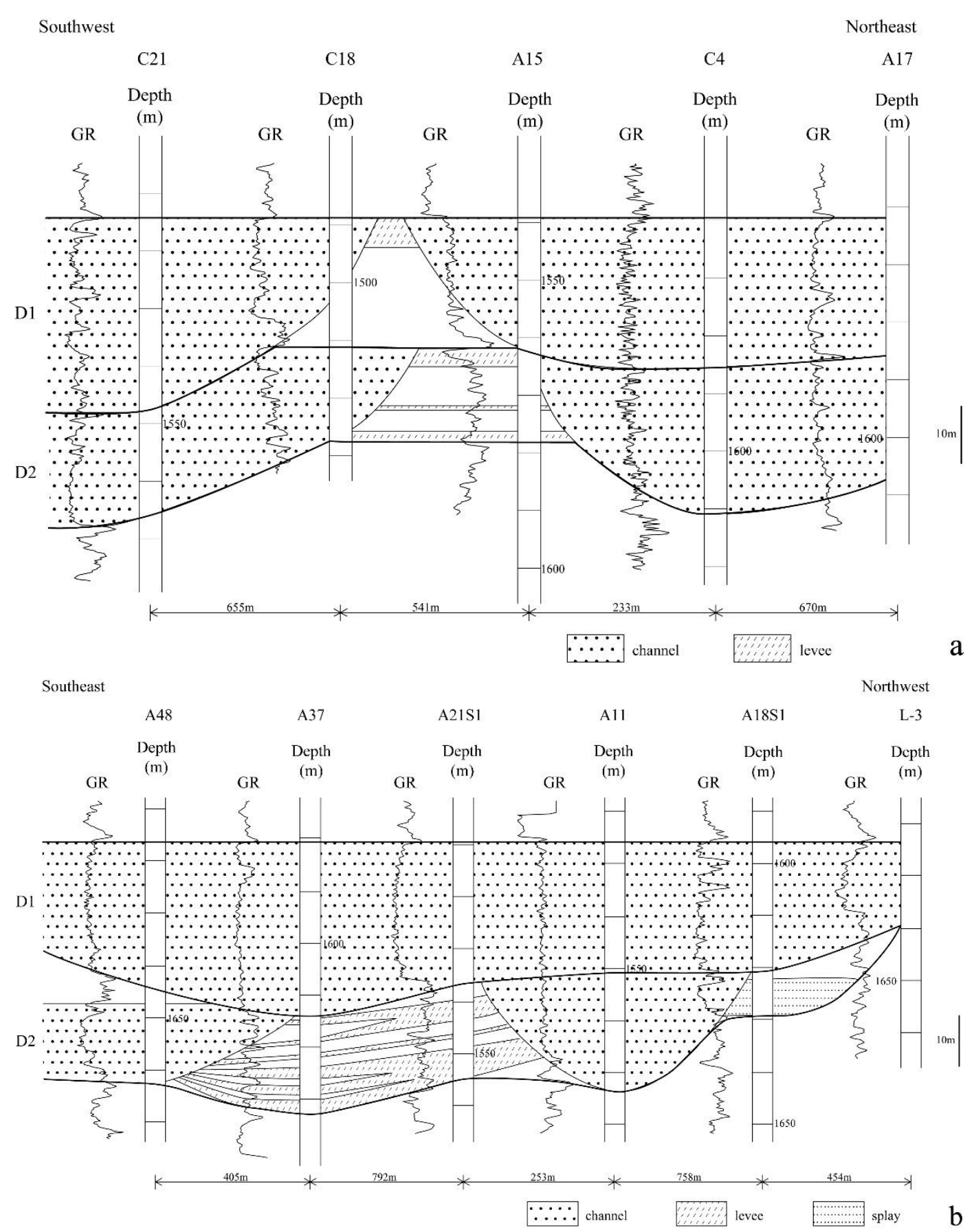

Figure 9. Cross sections, showing gamma-ray curve. Location of cross sections is shown in Figure 1b

The younger deposition in D1 interval prograded towards the lake basin in comparison with the elder deposition in D2 interval (Figure 10). Similar deposition pattern occurred in D1 and D2. In core, the D1 interval for Well A21S1 mainly includes medium to coarse grained sandstones and is interpreted to be deposited in channels. Whereas, the D2 interval in Well A21S1 core is finer grained, mainly including siltstones and fine sandstones, 
and is interpreted to be deposited in levees.
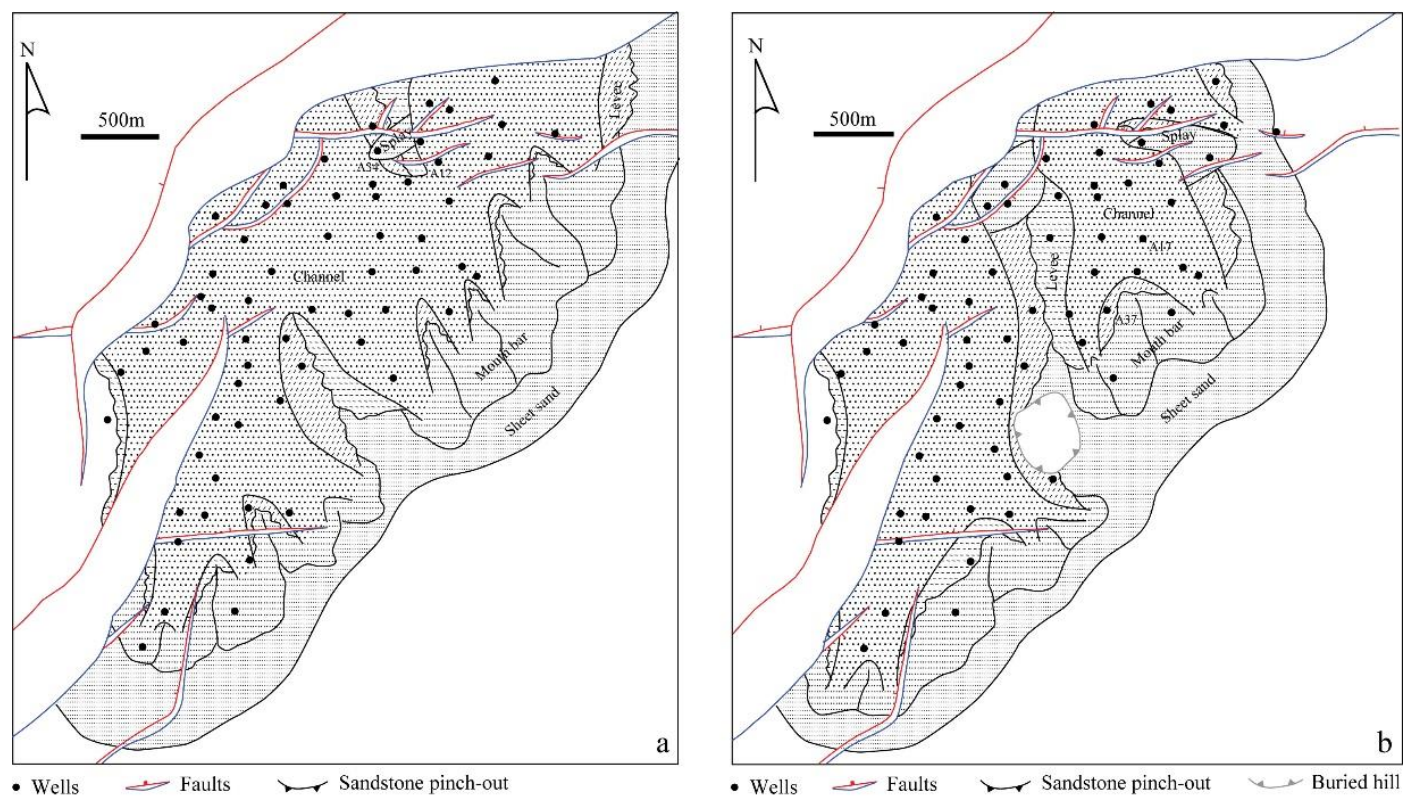

Figure 10. (a) Interpreted facies distribution of the D1 interval. (b) Interpreted facies distribution of the D2 interval. The location of wells discussed about reservoir performance are shown

\section{Reservoir Performance}

Although fluid production of $\mathrm{L}$ field is comingled between hydrocarbon-charged sandstones within the II through IV units, most production is provided by the D1 and D2 sandstones. Production from each interval can be inferred from thickness * permeability. As such, a trend of average daily total fluid production can reflect the historic performance of the D1 and D2 sandstones.

Facies distribution predicted for these two sandstones match trends of the daily total fluid production. Well A12 is one of the better wells in the field, with the average daily total fluid production from the D1 sandstone of $208 \mathrm{~m}^{3}$. Production from the D1 sandstone of Well A34 is lower, about $20 \mathrm{~m}^{3}$. One possible explanation for this is that Well A12 is located in a channel deposit, while Well A34 is located in a channel flank deposit with interbedded siltstones and lower permeability. A similar trend can be found in the average daily total fluid production of the D2 sandstone, as that from Well A17 and Well A37 of $92 \mathrm{~m}^{3}$ and $15 \mathrm{~m}^{3}$ respectively.

\section{Conclusions}

1) At $L$ field, the reservoir is subdivided into five oil layers that are designated the 0 , I, II, III, and IV. The II oil layer is the thickest and most widespread reservoir. And the D interval at the top of the IIoil layer is the primary production layer. The coarsening-upward $\mathrm{D}$ interval is a progradational parasequence set capped by a retrogradational parasequence set. Two progradational successions are recognized, including in ascending order the D2 and D1.

2) Six core facies are recognized and interpreted to accumulate within braided-river delta environments. And guidelines developed from open-hole well logs are used to predict depositional facies in wells lacking core control. Underwater distributary channels, channel-flanks, mouth bars, sheet sand and shalier interchannel deposits are deposited in the field. Reservoir sandstones consist of channels, channel-flanks and mouth bars. Core porosity in mouth bars ranges from 25 to $31 \%$; permeability ranges from 300 to $2200 \mathrm{mD}$. Underwater distributary channel sandstones have higher qualities, with porosity ranging from $29 \%$ to $35 \%$ and permeability from 1000 to $5500 \mathrm{mD}$. Channel-flank deposits have lower qualities, with porosity from $23 \%$ to $28 \%$ and permeability from 350 to $2000 \mathrm{mD}$.

3) During deposition, sandstones within the D interval are accreted as a southeastward prograding succession across the L field. The D1 sandstone is restricted more southeastern parts of the field than the D2 sandstone. 
Both sandstones widen but pinch out towards the southeastern part of the field and are thickest in the middle and pinch out along the margin on the either side.

4) Channel deposits are interpreted to occur along the trend of thickest D2 and D1 sandstones. Sandstones that flank each side of the channel deposits are interpreted to be levee and overbank splay deposits. Sandstones that develop at terminal distributary channel mouth are interpreted to be mouth bar and sheet sand deposits. Within the D1 and D2 sandstones, the predicted distribution of the higher reservoir quality facies corresponds to trends of better average daily total fluid production.

\section{References}

Dong, Y. X., Yang, S., Chen, L., Wang, Q., \& Cao, Z. H. (2014). Braided river delta deposition and deep reservoir characteristics in Bohai Bay Basin: A case study of Paleogene Sha 1 Member in the south area of Nanpu Sag. Petroleum Exploration and Development, 41, 385-393. https://doi.org/10.11698/PED.2014.04.01

Du, Z. M., Shi, J. A., Sun, G. Q., Ji, Y., Wu, Z. X., \& Tang, X. L. (2013). The Sedimentary Characteristics of Braided Delta of the Upper Xiaganchaigou Formation in Maxian Region of Qaidam Basin. Natural Gas Geoscience, 24, 505-511.

Guo, T., Wang, J., Shi, W. L., Zheng, J. G., Wang, B. Q., \& Xu, C. Q. (2012). Sequence stratigraphy of the Paleogene Dongying Formation and its significance for stratigraphic-lithologic reservoirs exploration in the central-south Liaoxi salient. Oil \& Gas Geology, 33, 248-255+264.

Guo, T., Zhou, X. H., Lai, W. C., Li, J. P., \& Shi, W. L. (2011). New sedimentary model and exploration discovery of Paleogene Dongying Formation in the middle section of the Liaoxi lower arch, China. Journal of Chengdu University of Technology (Science \& Technology Edition), 38, 619-624.

Ji, H. C. (2008). Sequence stratigraphy and depositional systems in the Paleogene, Liaodong Bay. Petroleum Science, 5, 110-118. https://doi.org/10.1007/s12182-008-0018-0

Ji, Y. L. (2005). Sequence Stratigraphy. Shanghai China: Tongji University Press (Chinese Version).

Lan, C. L., Wang, J. G., Zhou, X. F., Dai, J. Y., Yang, M. H., \& Cui, Z. Y. (2014). Impacts on sandstone reservoir quality of the Third Member of Upper Triassic Yanchang Formation, Penyang oilfield of Ordos Basin, China. Acta Petrologica Sinica, 30, 1828-1840.

Li, J. P., Zhou, X. H., \& Lv, D. Y. (2011). Distribution and evolution of Paleogene delta systems in Bohai sea. China Offshore Oil and Gas, 23(5), 293-298.

Li, W. H., Lin, J. Y., Yuan, M. S., \& Wang, W. H. (1996). Two types of coarse clastic delta in Turpan-Hami Basin. Acta Sedimentologica Sinica, 14, 115-123.

Li, W. L., Dai, C. M., \& Yu, S. (2006). Contrast of hydrocarbon accumulation conditions and hydrocarbon distributions between Liaodong Bay Fault Depression and Xialiaohe Depression. Journal of Xi'an Shiyou University (Natural Science Edition), 21(4), 15-19.

Li, Z. H., \& Huang, W. H. (2017). Lithofacies characteristics and sedimentary model of braided delta: a case study of He 8 member in the southern Sulige, Ordos Basin. Lithologic Reservoirs, 29(1), 43-50. https://doi.org/10.3969/j.issn.1673-8926.2017.01.006

Liang, H. B., Cui, Z. Q., Dong, X. Y., Li, H. E., Si, J. W., \& Wang, Y. J. (2011). Characteristics of Highstand Delta System and Play in Gentle Slop of Faulted Lacustrine Basin: A Case Study of Jiergalangtu Sag, Erlian Basin. Acta Sedimentological Sinica, 29, 783-792.

Lv, D. Y., Yang, M. H., Zhou, X. H., Wei, G., Liu, L., Li, C. X., \& Zheng, X. F. (2009). Structural characteristics and hydrocarbon accumulation in the buried hills of the Liaoxi low salient, the Liaodong Bay Depression. Oil \& Gas Geology, 30, 490-496.

Qi, J., Fu, H., Yu, J. W., Qi, L. Q., Shang, L., Wen, H. G., \& Xu, W. L. (2018). Sedimentary evolution of the Lower Jurassic Sangonghe Formation in Baijiahai uplift, Junggar Basin and its significance in oil and gas exploration. China Petroleum Exploration, 23(1), 81-90. https://doi.org/ 10.3969/j.issn.1672-7703.2018.01.009

Tian, J. C., Wu, Q., Wang, F., Lin, X. B., Zhang, J. Q., \& Cao, T. S. (2011). Research on development factors and the deposition Model of large area reservoir sandstones of He8 section of Xiashihezi Formation of Permian in Ordos basin. Acta Petrologica Sinica, 27, 2403-2412. 
Wang, J. (2010). Discovery of Braided River Delta in the Lower Member of Guantao Formation in Zhanhua Sag and Exploration Significance. Natural Gas Geoscience, 21, 974-979.

Wang, L. Q., Li, C., Li, Q. Z., Ma, K. Q., Li, H. Y., \& Zhu, H. Y. (2013). Reservoir sedimentology of Lvda 10-1 Oilfield in Liaodong Bay Basin. Lithologic Reservoirs, 25(5), 24-30.

Wang, L., Sun, X. P., Zhang, Y., \& Ma, X. Y. (2008). Necessary techniques studying on description of braid river delta lithologic oil/gas reservoir: A case of Liuxi structural belt. Oil Geophysical Prospecting, 43, 190-195.

Wang, X., Wang, Y. B., Lv, X. X., \& Fan, Q. H. (2011). Hydrocarbon accumulation conditions and distribution patterns in the Liaodong Bay Depression, the Bohai Sea. Oil \& Gas Geology, 32, 342-351.

Wang, Y., Yang, S. C., Bian, W., Luo, H. N., \& Wen, Y. R. (2012). Subdivision of the thick oil layer of braided river delta front: taking Tai 7 fault block in Xinjie Oilfield as an example. Journal of Xi'an Shiyou University (Natural Science Edition), 27(2), 13-16+117.

Wen, Z., Liu, Z. B., He, Y. B., Yuan, B. C., Luo, J. X., Pu, X. G., ... Lin, C. M. (2012). Sedimentation simulation experiment of braided fluvial delta of the second submember of Member 3 of Paleogene Shahejie Formation in Qikou Sag of Huanghua Depression. Journal of Palaeogeography, 14, 487-498.

Xu, G. S., Ma, R. L., Gong, D. Y., Zhou, D. H., Li, J. P., Guo, Y. H., .. Wu, C. R. (2011). Features of the fault system and its relationship with migration and accumulation of hydrocarbon in Liaodong Bay. Petroleum Science, 8, 251-263. https://doi.org/10.1007/s12182-011-0142-0

Yang, M. H., Zhou, X. H., Wei, G., Liu, L., Li, C. X., Zheng, X. F., ... Gao, L. B. (2008). Segment, linkage, and extensional fault-related fold in western Liaodong Bay Subbasin, Northeastern Bohai Sea, China. Journal of China University of Geosciences, 19, 602-610.

Yin, Z. J., Yu, X. Y., \& Lu, G. Y. (2006). Sedimentary facies of 8th member of Shihezi Formation in block Su6 in Sulige gas field. Natural gas industry, 26(3), 26-27+4.

Yu, X. H., Wang, D. F., \& Sun, Z. H. (1995). Lithofacies types, vertical profile features and reservoir geological models of braided deltaic sandbodies in faulted lake basin: The observation on deposition of modern deltas in Daihai lake, Inner Mongolia. Acta Sedimentologica Sinica, 13, 48-58.

Zhang, C. H., Cheng, F., Huang, G. P., Xing, C., Guan, B., Zhang, Q. Y., \& Xu, G. (2013). Sediment and reservoir characteristics with reservoir evaluation of Lulehe Formation in Qie 16 block of Kunbei oilfield in Qaidam Basin. Acta Petrologica Sinica, 29, 2883-2894.

Zhu, X. M. (2008). Sedimentology. Beijing China: Petroleum Industry Press (Chinese Version).

Zhu, X. M., Deng, X. Q., Liu, Z. L., Sun, B., Liao, J. J., \& Hui, X. (2013). Sedimentary characteristics and model of shallow braided delta in large-scale lacustrine: An example from Triassic Yanchang Formation in Ordos Basin. Earth Science Frontiers, 20(2), 19-28.

Zhu, X. M., Dong, Y. L., Yang, J. S., Zhang, Q., Li, D. J., Xu, C. G., \& Yu, S. (2008). Sequence stratigraphic framework and distribution of depositional systems for the Paleogene in Liaodong Bay area. Science in China Series D: Earth Sciences, 51, 1-10. https://doi.org/10.1007/s11430-008-6011-z

Zhu, X. M., Pan, R., Zhao, D. N., Liu, F., Wu, D., Li, Y., \& Wang, R. (2013). Formation and development of shallow-water deltas in lacustrine basin and typical case analyses. Journal of China University of Petroleum, 37(5), 7-14. https://doi.org/10.3969/j.issn.1673-5005.2013.05.002

Zhu, X. M., Zhong, D. K., Yuan, X. J., Zhang, H. L., Zhu, S. F., Sun, H. T., ... \& Xian, B. Z. (2016). Development of sedimentary geology of petroliferous basins in China. Petroleum Exploration and Development, 43, 820-829. https://doi.org/10.11698/PED.2016.05.20

\section{Copyrights}

Copyright for this article is retained by the author(s), with first publication rights granted to the journal.

This is an open-access article distributed under the terms and conditions of the Creative Commons Attribution license (http://creativecommons.org/licenses/by/4.0/). 